\title{
Property Theft Enforcement and the Criminal Secondary Purchaser of Stolen Goods
}

Approximately ninety percent of all serious offenses reported in the United States involve property theft. ${ }^{1}$ Crimes against property were estimated to occur every three seconds in $1978^{2}$ and to cost American consumers as much as $\$ 20.3$ billion annually. ${ }^{3}$ Despite the damaging effect of such crimes on the community, fewer than twenty percent of the known incidents are cleared by arrest. ${ }^{4}$

There have been two major law enforcement responses to the problem of property theft. The traditional approach is aimed at arrest and prosecution of the thief. Recently, this approach has been supplemented by increased concentration on the thief's immediate market for his products, the fence. ${ }^{5}$ Even the combination of these two approaches, however, has had little noticeable effect on the incidence of property theft. This failure is attributable to a number of factors, the most obvious of which is the difficulty of apprehending and prosecuting thieves and fences. Conviction of thieves is difficult, in part because a

1. See Federal Bureau of Investigation, U.S. Dep't of Justice, Uniform Crime RePORTS FOR THE UNITED STATES-1978, at 35 (1979) (crimes reported in 1978) [hereinafter cited as Uniform CRIME Reports-1978]. These statistics, compiled by the Federal Bureau of Investigation, include criminal homicide, forcible rape, robbery, aggravated assault, burglary, larceny, and motor vehicle theft. The term "property crime" includes burglary, larceny, and motor vehicle theft, but does not include robbery (taking through force or threat of force). Because statistics obviously cannot include crimes that are never reported, the property theft problem may be far greater than statistics show. See U.S. DEP'T of Justice, Sourcebook of Criminal Justice Statistics-1977, at 303, Table 3.2 (1977) (more than $50 \%$ of thefts may never be reported to police).

2. UNIFORM CRIME REPORTs-1978, supra note 1 , at 6.

3. See Blakey \& Goldsmith, Criminal Redistribution of Stolen Property: The Need for Law Reform, 74 Mich. L. REv. 1511, 1517-18 (1976).

4. The ineffectiveness of the criminal justice system's response to crimes against property was emphasized in a study conducted more than a decade ago. President's CoMm'N ON Law Enforcement \& Administration of Justice, The Challenge of Crime in a free SOCIETY 4 (1967) (prevalence of burglary and robbery a significant reason for nation's alarm about crime, and protecting community from those two crimes would do much to make crime as a whole less frightening). In 1978, however, police cleared only $18.1 \%$ of such crimes. Uniform Crime RePorTs-1978, supra note 1, at 177, Table 20. The 1967 clearance rate was approximately $19.3 \%$. See Fcderal Bureau of Investigation, U.S. DeP'T of Justicc, Uniform Crime Reports for the United StATes-1967, at 109, Table 16 (1968) (based on 1977 definitions of property crimes but fewer cities included in 1967 calculation).

5. The term "fence" is the colloquial expression for the criminal receiver of stolen goods. M. Walsh, The Fence 4 (1977). More accurately, a fence is a commercial criminal receiver of stolen goods who intends to profit by reselling the merchandise. This commercial aspect distinguishes the fence from the "lay" criminal receiver who buys for personal consumption. Commercial receivers have been termed either "occasional" or "professional," according to the amount of their criminal activity. See J. Hall, TheFT, LAW AND SOCIETY 155 n.I (2d ed. 1952). 
thief can quickly dispose of the evidence of his crime by selling the stolen property to a fence. ${ }^{6}$ Conviction of fences is also difficult; the criminal receiver of stolen goods is notorious for his insulation from the justice system. ${ }^{7}$ There is an additional problem, however, that relates to enforcement policy: ${ }^{8}$ efforts directed only at thieves and fences who buy from thieves may ignore the parties who potentially provide the ultimate economic motivation for property theft, the secondary purchasers. These purchasers, who buy stolen goods from fences, can be the key element in the incentive structure that supports property crime. When such individuals are present in the redistribution channel, law enforcement strategies that neglect them overlook a significant source of the economic motivation behind property theft.

This Note argues that increased attention should be given to detecting and prosecuting the criminal customers of a fence. Because secondary purchasers are integral components of the social and economic conditions motivating thefts, deterrence of such offenders could substantially reduce the profits of the primary fence and thieves and thereby reduce the incidence of property crimes as well. Furthermore, criminal secondary purchasers may be both easier to detect and easier to deter than the other criminal participants in the redistribution channel for stolen goods.

\section{The Channel of Stolen Property Redistribution}

Thieves rarely steal for personal consumption. ${ }^{9}$ They steal for profit and so rely on the existence of an immediate market for stolen prop-

6. Blakey \& Goldsmith, supra note 3, at 1514 .

7. See J. HALL, supra note 5, at 195 ("Indeed, the history of receiving stolen property might be written in terms of the difficulties of convicting these offenders."). For a detailed account of the historical development and inadequacies of criminal sanctions applied to the receivers of stolen goods, see Blakey \& Goldsmith, supra note 3, at 1542-1601.

8. Problems associated with enforcement policies are difficult to discern from statistics because available statistics on criminal receivers are misleading. See Criminal Redistribution Systems and their Economic Impact on Small Business: Hearings Before the Senate Select Committee on Small Business, 93d Cong., Ist Sess. 8 (1973) (statement of Joseph P. Busch, District Attorney, County of Los Angeles) (statistics misleading because many burglars plead or are convicted of criminal receiving) [hereinafter cited as Hearings]. However, recent books and articles designed to shift enforcement attention from the thief to the primary fence, see, e.g., Law Enforcement Assistance Administuation, U.S. Dep't of Justice, Strategies for Combatting the Criminal Rrceiver of Stolen Goods (1976) [hereinafter cited as Strategies]; Blakey \& Goldsmith, supra note 3, give a fairly accurate representation of current enforcement policy. Interview with Dr. Marilyn Walsh, Research Scientist, Batelle Law \& Justice Study Center, in Seattle, Washington (June 25, 1979) (notes on file with Yale Law Journal) [hereinafter cited as Walsh Interview].

9. Blakey \& Goldsmith, supra note 3 , at 1514; cf. Hearings, supra note 8, at 3 (Statement of Joseph P. Busch, District Attorney, County of Los Angeles) ("[B]urglars depend totally on fences for their existence."). 
erty. ${ }^{10}$ This market consists of both "commercial" receivers, who resell the merchandise, and "lay" receivers, who consume the goods. ${ }^{11}$ Vertical redistribution from thief to consumer may involve a series of levels. ${ }^{12}$ At the primary level, the thief transfers property to a first purchaser, usually a commercial receiver..$^{13}$ Commentators have identified a spectrum of these offenders with varying degrees of criminal involvement and influence; ${ }^{14}$ while some may deal only occasionally in stolen property, others may maintain sophisticated organizations for this purpose and may even supply thieves with advance orders for illicit merchandise. ${ }^{15}$

At the secondary and any subsequent levels, the intermediary receiver transfers the property to a purchaser who may be either commercial or lay. ${ }^{10}$ These secondary purchasers have in common that they are all customers of commercial receivers. Like legitimate merchandise in a legitimate market, a stolen article may pass through several business establishments before reaching an ultimate consumer.

Even though the redistribution channel may involve many participants, only those who are aware that the merchandise is stolen are guilty of criminal conduct. ${ }^{1 \tau}$ The number of aware participants in a

10. Hearings, supra note 8 , at 159 (letter from Robert Earl Barnes) (thieves steal what can be sold and better thieves sell before they steal).

11. See note $\mathbf{5}$ supra.

12. See Roselius \& Benton, Marketing Theory and the Fencing of Stolen Goods, 50 DEN. L.J. 177, 191-92 (1973) (discussing factors affecting length of channels of distribution).

13. See id. at 184 .

14. See, e.g., Strategies, supra note 8, at 10 (list of fencing roles from most passive to most active); Blakey \& Goldsmith, supra note 3, at 1529-42 (types of fencing activity in-

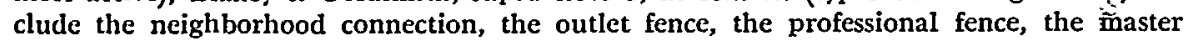
fence, and organized crime).

15. Strategies, supra note 8 , at $9-10$; Hearings, supra note 8 , at $30-36$ (testimony of Miss A. Jones); Blakey \& Goldsmith, supra note 3 , at 1536.

16. Both commercial and lay criminal secondary purchasers have been acknowledged to be part of the property theft problem. The secondary fence may be a "neighborhood" fence working with a professional receiver who specializes in wholesaling. Blakey \& Goldsmith, supra note 3, at 1530 n.111. He may be an "outlet" fence, such as an employee in a large retail establishment who buys stolen goods disguised as legitimate from professional or master fences. Id. at 1531 . The arrangements for such sales may even be made before the theft is engineered. Id. at 1536. Other secondary fences may buy stolen goods from organized crime syndicates operating as primary receivers and "funneling stolen goods through interstate commerce. ..." Id. at 1541 .

The lay criminal receiver, or consumer, is also a problem in some redistribution networks. Id. at 1520 ("[T] he survival of criminal redistribution systems depends upon the continued propensity of consumers and businesses to buy illegal goods.") (footnote omitted); Roselius \& Benton, supra note 12, at 202 (discussion of potential benefits derived from reduction of market demand for stolen goods); Chasan, Good Fences Make Bad Neighbors, N.Y. Times, Dec. 29, 1974, $\$ 6$ (Magazine), at 17 (low prices of stolen goods naturally attract consumers).

17. Mens rea, or "guilty mind," is an element of the statutory offense of receiving stolen goods. See, e.g., CaL. Pensl Code $\$ 496(1)$ (West 1970) (knowing); Conn. Gen. 
particular channel depends on a variety of factors but is largely determined by characteristics of the property transferred, ${ }^{18}$ such as the condition of the property at the time of theft, ${ }^{19}$ its resale value, storage requirements, and salability by a particular receiver. ${ }^{20}$

\section{The Need for Additional Enforcement Strategies}

Of the various criminal participants in redistribution channels, the thief traditionally has attracted the preponderance of law enforcement attention. ${ }^{21}$ Although the relationship between theft and the criminal receiver of stolen goods has been acknowledged since the early eighteenth century, ${ }^{22}$ only recently have enforcement resources been directed against this offender. ${ }^{23}$

Stat. ANN. § 53a-119(8) (West Supp. 1979) (knowing or believing); Ill. ANN. Stat. ch. 38, $\$ 16-1$ (d) (Smith-Hurd 1977) (same). When a statute requires the receiver to know that the goods have been stolen, it has been held that a jury need only find that the receiver could infer the theft from the circumstances of the salc. United States v. Werner, I60 F.2d 438, $441-42$ (2d Cir. 1947).

Secondary purchasers with guilty knowledge may or may not be present in particular redistribution channels. Some authorities have indicated that aware secondary purchasers are part of the local redistribution system. Telephone Interview with Detective Kirkendall, Miami, Florida Fencing Squad (Aug. 28, 1979) (notes on file with Yale Law Journal); Telephone Interview with Sgt. McFarland, St. Louis County Dep't of Police, St. Louis, Missouri (August 29, 1979) (notes on file with Yale Law Journal). Others believed that in most cases the thief and the primary fence were the only criminal participants in stolen goods redistribution channels. Telephone Interview with Larry McNeely, Fencing Analyst, California Dep't of Justice, Sacramento, California (August 28, 1979) (notes on file with Yale Law Journal); Telephone Interview with Sgt. Harry Boggs, Portland, Oregon, Police Dep't Fencing Detail (July 3, 1979 and Sept. 11, 1979) (notes on file with Yale Law Journal) [hereinafter cited as Boggs Interview].

18. Law Enforcement Assistance Administration, U.S. Dep't of Justice, Taking the Offensive 9 (Nov. 22, 1978) ("The nature and extent of the [stolen property distribution] system is primarily determined by the property itself.") [hereinafter cited as Taking the Offensive]. Differences between consumers also may affect the length of the redistribution channel. According to one analysis, if the consumer is aware that the merchandise is stolen, the thief may sell the goods directly or use a fence as a type of broker. If a consumer is unaware, or if the intended customer is an industrial concern, the stolen character of the merchandise must be disguised and one or more fences may be required. Roselius \& Benton, supra note 12, at 191-92.

19. For example, when new, crated shipments are stolen from airports and seaports, the thief may be able to sell the merchandise directly to a large retail outlet. The stolen merchandise can be intermingled with legitimate items and then sold at full market price to an unsuspecting customer. At the other extreme, the marketing of easily identifiable secondhand merchandise obtained from residential and commercial thefts may require a willing and aware consumer or the involvement of intermediary receivers who disguise or transport the stolen goods. See Roselius \& Benton, supra note 12, at 191-92.

20. See Taking the Offensive, supra note 18 , at 9 .

21. Strategies, supra note 8, at 3; Blakey \& Goldsmith, supra note 3, at 1514.

22. The prosecution of Jonathan Wild evidences this early awareness. Wild, called the Father of Professional Fencing, was brought to trial in London in 1725. C. KLockARs, THE Professional Fence 3-27 (1974). Several of the offenses with which he was charged related to the assistance he provided to thieves. 2 G. Borrow, Celebrated Trials 502-04 (1928).

23. See Strategies, supra note 8 , at 3 . 


\section{A. Enforcement Against Thieves}

The thief's predominant position in enforcement policy is natural because the act of stealing generally leaves behind both a potential complainant and an immediate sense of danger in the community. ${ }^{24}$ However, as the high incidence and low conviction rates for reported thefts suggest, ${ }^{2 \overline{ }}$ this focus on the thief has proven ineffective.

Various weaknesses have been recognized in the conventional approach. ${ }^{20}$ First, the individual crimes are difficult to solve. Because police investigations begin only some time after a theft occurs, time generally favors the criminal. ${ }^{27}$ Solution is arduous and costly-victims must be interviewed and willing witnesses sought; the crime scence must be examined to collect physical evidence. ${ }^{28}$ Second, this approach to property crime ignores the thief's market for stolen goods, and in so doing fails to lessen the economic motivation for theft. ${ }^{29}$ Because police traditionally respond to victim complaints, when the thief is apprehended, the crime often is considered solved ${ }^{30}$ But apprehension of

24. Traditional theft enforcement policy is reactive; police respond to complaints. Taking the Offensive, supra note 18, at 8 . Although most criminal acts are reported to police by their victims, an easily discerned criminal act may be reported by anyone who happens upon the scene of the crime. P. Weston \& $\mathrm{K}$. Wells, The Administration of Jusrice 36 ( $3 d$ ed. 1977). Fencing activity is covert and only indirectly harms the theft victim, who is unlikely to be aware of it. Only the criminal distributors themselves are apt to have knowledge of the illicit activity. Thus fencing is unlikely to be the subject of a complaint by either the victim or others. Police may become aware of fencing activity only through statistical indicators, such as high theft rates coupled with low clearance rates and low property recovery rates, information received from theft offenders, and because of the incidence of collateral crimes, such as tax fraud or failure to comply with business licensing regulations. STRATEgies, supra note 8 , at 22-26.

25. See note 3 supra.

26. M. WALsh, supra note 5, at $172-74$ (weaknesses include post-hoc quality of enforcement efforts, assumption that catching thief solves the crime, and failure to focus on redistribution system).

27. Id.; P. Weston \& K. Wells, Criminal Investigation 242 (1970).

28. P. Weston \& K. Wells, supra note 27, at 241; cf. Walsh, Reassessing Your Agency's Property Crimes Enforcement Mission 4 (March 1979) (Introduction on file with Yale Law Journal) (because of thieves' declining skills and less distinctive modus operandi in last 20 years, criminal justice system's ability to identify thieves from evidence at crime scene has declined).

The authors of a 1971 study of New York City felonies noted with respect to burglaries: The lower clearance and arrest rates might be explained by a lack of face-to-face contact in most burglaries. In assault, attempted murder, rape and robbery, the victim has at least seen the perpetrator once. But the "real," professional burglar will make his getaway before the crime is discovered, and the police acknowledge that the chances of finding and linking him with the crime are slim. Thus, the courts are likely to be processing a minority of burglars unlucky or incompetent enough to be caught, or who are already known to their victims.

Ver Institute of Justice, Felony Arrests: Their Prosecution and Disposition in New YORK CITY's Courts 81-82 (1977).

29. M. WALSH, supra note 5 , at 172-74.

30. Id. at 173 . 
the individual thief leaves his market untouched; demand persists and new thieves may step in to replace him if the arrest removes him from the redistribution channel. Thus, the overall level of property theft may not be appreciably altered.

In response to these problems, property theft enforcement strategies and policies are changing. Tactics are being utilized that attract unknown offenders to undercover officers posing as primary fences. ${ }^{31} \mathrm{Al}$ though this storefront, or "sting," operation has been criticized,;2 some recent improvements in property theft statistics may be attributable to its use. ${ }^{33}$ Additionally, police are becoming more concerned with the market for stolen goods. When a thief is apprehended, enforcement authorities increasingly attempt to elicit information about his fence. ${ }^{34}$

\section{B. Enforcement Against Primary Fences}

The ineffectiveness of concentrating enforcement efforts exclusively on thieves has led to increased efforts to apprehend their fences. In many ways, however, the fence presents an even more difficult enforcement challenge. Detection of the very commission of the crime is problematic. Unlike a theft, the crime committed by a fence leaves no likely complainants-anyone who knows of the fence's criminal activity

31. The Law Enforcement Assistance Administration has put major emphasis on socalled "sting" operations. Law Enforcement Assistance Administration, U.S. Dep't of Justice, Some Benefits Realized from Twelve Sting-Type Anti-Fencing Operations 1-2 (June 30, 1977) [hereinafter cited as Benefits Realized]. Since 1974, more than 60 "sting" projects have been conducted in 39 jurisdictions. LAw ENFoncement Assistance AdministraTION, U.S. DeP'T OF JUSTICE, What HAPPENEd 1-1 (1979). A recent newsletter suggests that the number of such projects continues to grow. Antifencing Program Recovers $\$ 200$ Million in 5 Years, 8 LEAA NewSLETTER 6 (November 1979) (85 "sting" projects concluded in 46 cities) [hereinafter cited as Antifencing Program].

In the storefront "sting" tactic, police pose as primary fences for the purpose of penetrating the stolen property redistribution system. Transactions are videotaped and, after sufficient evidence is collected, the thieves and competing primary fences are arrested. Taking the Offensive, supra note 18 , at 1 .

32. Some criticisms focus on the characterization of this technique as an antifencing strategy. See, e.g., Benefits Realized, supra note 31; Taking the Offensive, supra note 18. In reality, fewer than one in five of the subjects apprehended and/or identified in "stings" have been classified as fences. Anti-Fencing Program, supra note 31, at 6. Because the great majority of arrestees are thieves, commentators reject the storefront as an antifencing tactic. STRATEgIes, supra note 8, at 95-96. Other criticisms focus on the rationale behind strategies that target the unknown offender. Because the procedure attracts unidentified thieves who want to sell stolen goods, the "sting" is considered by some to be a procedure whereby tax money is used to buy back stolen property that the thieres may have been encouraged to steal because of the available market provided by the police. $I d$.

33. See Benefits Realized, supra note 31, at 3-10 to 3-13.

34. Information about fences may have been collected previously to get fences to cooperate as informants against particularly notorious thieves who aroused public resentment. Strategies, supra note 8, at 4-5; Chappell \& Walsh, Receiving Stolen Property: The Need for Systematic Inquiry into the Fencing Process, 11 CRIMINoLogy 484, 490 (1974). 
is probably also criminal, and is helped, not harmed, by the crime. Therefore, the antifencing strategies that have been developed rely primarily on thieves for information about illegal fencing activity. ${ }^{35}$ Once information concerning specific offenders has been collected in this manner, enforcement efforts typically employ surveillance and, often, undercover agents posing as thieves or purchasers in order to obtain sufficient evidence for conviction. ${ }^{36}$

Reliance on thieves as sources of information creates other problems, however. In order to obtain conviction of a fence, enforcement authorities must be prepared to compromise cases against thieves and perhaps to grant immunity in order to secure their cooperation. ${ }^{37}$ Although the fence, arguably, deserves higher priority than thieves in property theft enforcement, ${ }^{38}$ reluctance to make this trade-off persists ${ }^{39}$ and antifencing strategies remain a small part of the criminal law enforcement effort. ${ }^{40}$

In addition, thieves deal only with the primary receiver in the redistribution channel, by definition. Thus, identification of specific secondary criminal receivers must proceed by other means. Virtually no known strategies are currently employed for this purpose. ${ }^{41}$

\section{Toward a New Strategy: Allocating Enforcement Resources to Criminal Secondary Purchasers}

Current enforcement strategies would be enhanced by increased efforts to detect and prosecute criminal secondary purchasers of stolen goods. Because such purchasers may be both easier to detect and easier to deter than are either primary fences or thieves, the utility of shifting a small portion of property theft enforcement resources to such efforts

35. See Strategies, supra note 8 , at 74 (antifencing strategies have in common use of the thief as investigative tool or evidentiary device rather than as target).

36. Id. at $76 \cdot 82$.

37. Id. at 74; Blakey \& Goldsmith, supra note 3, at 1563-65.

38. Blakey \& Goldsmith, supra note 3 , at 1565.

39. Id. Several reasons have been advanced to explain this reluctance, including public acceptance and lack of moral condemnation for the crime, the fence's integration into the legitimate socioeconomic structure, his relationship with enforcement authorities, and the difficulty of penetrating his operation in situations in which he has connections with organized crime. Chappell \&. Walsh, supra note 34 , at 487-92.

40. Walsh Interview, supra note 8.

41. One type of antifencing enforcement tactic that could have reached knowing secondary purchasers was a project in which undercover officers peddled allegedly stolen merchandise to business people in the community suspected of buying stolen goods from thieves and fences. Although not designed specifically to detect secondary purchasers, this strategy did not require information from thieves with whom the secondary purchaser may not have contact. Boggs Interview, supra note 17. 
can be expected to be greater than the utility of using these same resources as they are presently employed. In order to effectuate such a shift, certain modifications in the substantive criminal law should be made in some states and new enforcement strategies should be developed and implemented.

\section{A. Criminal Secondary Purchasers: Motives and Deterrents}

Although the criminal laws of every state proscribe the knowing purchase of stolen goods, ${ }^{42}$ the market continues to absorb such merchandise "just like a huge dry sponge." 43 An understanding of this market is essential to development of appropriate deterrents.

While all purchasers of stolen goods probably are attracted by low prices, ${ }^{44}$ secondary criminal purchasers may have identifiable behavioral characteristics that differentiate them from primary fences. First, secondary criminal purchasers probably have smaller economic gains from their purchases and, therefore, are likely to be less motivated to engage in the illegal conduct than are primary receivers. ${ }^{45}$ Second, because secondary purchasers deal with fences rather than with thieves, and thus are somewhat removed from thefts, secondary purchasers are likely

42. See, e.g., Conn. Gen. Stat. ANs. § 53a-119(3) (West Supp. 1979) (anyone who knowingly, or with belief, receives, retains, or disposes of stolen property is guilty of offense); ILL. ANN. STAT. ch. 38, § 16-1(d) (Smith-Hurd 1977) (offense committed by anyone who knowingly, or with reason to believe, obtains control over stolen property).

43. S. Rep. No. 1318, 93d Cong., 2d Sess. 3 (1974). The fact of illegality, absent enforcement, has had little deterrent effect. See Hearings, supra note 8, at 4 (statement of Joseph P. Busch, District Attorney, County of Los Angeles) ("Too many legitimate businessmen are willing to buy hot merchandise, if it assures them of a higher profit."); $i d$. at 161 (letter from Robert Earl Barnes) (" $[\mathrm{I}] \mathrm{t}$ is easier to sell something that is stolen than it is to sell a legitimate item."). Vincent "Swaggi," a professional fence interviewed by one commentator, perhaps best described public response:

See, most people figure all of the stuff in my store is hot, which you know it ain't.

But if they figure it's hot you can't keep 'em away from it. . . . You think I'm gonna

tell 'em it ain't hot? Not on your life. In fact I tell 'em it is hot.

C. KLockars, supra note 22 , at 79 .

44. See C. KLockars, supra note 22, at 62 ("Everybody's looking for a bargain . . . . If the price is right and a man can use the merchandise, he's gonna buy. No question about it."); Roselius \& Benton, supra note 12, at 190 (primary attraction is the lowerthan-wholesale price).

45. As in the legitimate marketplace, in the market for stolen goods the number of distributors (primary fences) who deal directly with manufacturers (thieves) should be considerably less than the number of retailers, wholesalers, and consumers on subsequent distribution levels. Thus, it is reasonable to assume that most secondary criminal purchasers engage in less criminal conduct, that is, deal in a smaller volume of stolen goods, than do most primary receivers. This suggests that the economic gains of individual secondary purchasers from their criminal conduct are probably smaller than those of primary purchasers. Moreover, higher profits may be demanded at the primary level as compensation for the risks and costs associated with dealing with thieves. See pp. 1235-30 infra. 
to feel less criminal than either primary fences or thieves. ${ }^{46}$ Furthermore, they may rationalize that others will buy the low-priced goods if they do not. ${ }^{47}$ These factors make it easier for individual secondary criminal purchasers to ignore the critical connection between their own unlawful behavior and the high level of property theft in the community, and, thus, the negative consequences of their purchases on prior and future theft victims. ${ }^{48}$

These factors suggest that secondary purchasers may be more easily deterred than primary purchasers. It has been recognized that enforcement threats are more likely to deter individuals who have weaker motivations for their criminal conduct, ${ }^{40}$ who see themselves as less criminal, ${ }^{50}$ and who engage in apparently minor, rationally motivated

46. Although criminal secondary purchasers may know that their conduct is unlawful, the lack of enforcement and the lack of public condemnation suggest that buying stolen goods from a fence is more socially acceptable than buying from a thief. Thus, a receiver's decision to deal with a fence rather than a thief may reflect a desire to appear less criminal. See Hearings, supra note 8, at 44 (statement of Franklyn H. Snitow, Assistant District Attorney, New York County, N.Y.) ("No god-fearing honest merchant will buy 'hot' goods directly from a thief, but a few do not mind buying from a well-mannered, elegantly dressed fence....")

47. A purchaser may argue that his private refusal to buy stolen goods would have an inconsequential effect on the amount of theft. One writer maintains:

I do not believe that a rational economic argument can be made against an individual decision to buy stolen goods. The claim that theft costs everyone as reflected in higher costs and insurance rates is inadequate. It costs everyone surely, but those who buy stolen goods manage to offset thesc higher costs and rates. In fact, were it simply a question of a personal economic strategy, one might argue that the only way to beat the consequences of the thieves' market is to patronize it.

C. KLOCKARS, supra note 22 , at 150 .

48. The crime of receipt of stolen goods has a real victim, the victim of the theft, even though his identity may be unknown to the receiver. This serves to differentiate the purchase of stolen goods from other illegitimate buyer-supplicr markets. In narcotics, for example, the lack of enforcement against users as opposed to drug sellers may reflect public recognition that the former primarily harm themselves. See 2 Working P.IPERs of the National Comm'N on Reform of Federal Criminal Laws 1102 (1970) (distributors pose greater threat, more directly involve other persons, and evoke less benevolent feelings than users, and thus are more appropriate target for law enforcement) [hereinafter cited as Working Papers].

Because the theft victim is distant and unknown, unlawful purchasers may believe the bureaucratic system is the only victim. See Roselius \& Benton, supra note 12, at 190 (consumers of stolen goods may be motivated by the prospect of "beating the system"). Indeed, the community may consider the sale of stolen goods to be a "social service for the hardpressed consumer." Chappell \& Walsh, supra note 34, at 491-92.

49. F. ZimRing \& G. Hawkins, Deterrence 135-36 (1973).

50. See N. Morris, The Habitual Criminal 13 (1951) (concluding that "the effectiveness of deterrence varies in inverse proportion to the moral scriousness of the offense"). The fact that deterrence is more effective for minor offenses may be due "to the impact of threats on persons for whom a deterrent threat is not necessary to prevent more serious criminality." F. ZimRING \& G. HAwkins, supra note 49, at 134. Thus, persons who feel less criminal probably are more responsive to enforcement threats that highlight their criminality. Two examples may be found in shoplifting and prostitution enforcement. Certain shoplifters, known as pilferers, like criminal secondary purchasers of stolen goods 
crimes. ${ }^{51}$ Although all criminal secondary purchasers may not have these characteristics, some clearly do, and it is a fair generalization that a greater proportion of secondary than primary receivers correspond to this profile of the more easily deterred offender. Thus, allocation of a portion of property theft enforcement dollars for deterrence of criminal secondary purchasers could increase the marginal utility of those dollars. Secondary purchasers should respond to an enforcement risk; some should be completely deterred and others should at least be made more cautious, their purchases less frequent. Furthermore, even minimal enforcement, if coupled with widespread communication of the new enforcement approach, could have a far-reaching effect. ${ }^{52}$

\section{B. Economic Effects of Enforcement Against Criminal Secondary Purchasers}

Deterrence of criminal secondary purchasers could have a significant impact on the economic conditions motivating property theft, and thus on its incidence. The amount of theft is limited by the rate at which stolen goods can be sold to the public. ${ }^{53}$ This economic motivation for the crime suggests that enforcement against criminal participants in the redistribution channel may decrease the amount of illegal activity in more than one way. Not only can particular offenders be incapacitated through arrest and removal from the community, ${ }^{54}$ but, in ad-

who buy occasionally or for personal consumption, may be respectable people not in contact with a criminal subculture. One theory advanced to explain the low rate of recidivism of shoplifters who are apprehended but set free is that the experience forced them to view themselves as thieves. M. Cameron, The Booster and the Snitcil 151-65 (1964). Similarly, in prostitution enforcement, resources are more effectively applied to patrons of prostitutes than to the prostitutes themselves, despite the fact that a single prostitute has many more contacts and is easier to detect. Jennings, The rictim as Criminal: A Consideration of California's Prostilution Law, 64 CALIF. L. Rev. 1235, 1281 (1976). Thus, by analogy, secondary purchasers, like patrons of prostitutes, may be more threatened by the risk of enforcement than are more criminally engaged participants.

51. F. ZimRing \& G. Hawkins, supra note 49 , at 135-36.

52. See id. at 147 ("Formal and informal channels of communication-including newspaper and television accounts of the new threat and stories of those punished for lawbreaking-will bring the message to members of the threatened audience.")

53. Chamberlain, Anti-Fence Legislation, 14 A.B.A.J. 517, 517 (1928); see P. Colquhoun, A Treatise on the Police of the Metropolis 173 (3d ed. London 1796) ("Nothing . . . can be more just than the old observation, 'that if there were no Receivers there would be no thieves.'-Deprive a thief of a sale and ready market for his goods, and he is undone.") (italics in original); J. HaLL, supra note 5 , at 161 (receiver is as dependent on market for stolen goods as thief).

54. See Ehrlich, Participation in Illegitimate Activities: An Economic Analysis, in Essays in the Economics of Crime and Punishment 68, 83 (G. Becker \& W. Landes eds. 1974). This factor may be less significant in the case of thieves than in the case of other criminals in the redistribution channel, because it is likely that the amount of theft may be dictated in large part by primary market demand for stolen goods. If so, when onc thief is removed from the redistribution channel, another may take his place. 


\section{Stolen Goods}

dition, the risks and costs to all offenders can be raised, thereby making the conduct less profitable, and so, less attractive. ${ }^{55}$

Enforcement against thieves affects the rate of property theft directly: it both removes thieves from the redistribution channel and raises the risks associated with thefts so that a thief will require a higher rate of return in order to continue his illegal activities. ${ }^{56}$ Enforcement against primary fences seeks to achieve similar effects indirectly. If the primary fence is apprehended and removed it may increase the risks to thieves in two ways: the fence may testify against his thieves, and his thieves will have to find new fences or attempt to peddle the stolen goods themselves. ${ }^{57}$ In addition, enforcement against primary fences should raise the risks and costs of operation to these receivers, cutting into their profits so that they, too, will require a higher rate of return. This need for higher profits has a spiraling deterrent effect. If primary fences lower the prices paid to thieves or raise the prices charged to customers, they decrease the economic incentives to those parties to engage in their criminal acts. If thieves or customers decrease their criminal behavior, supply or demand respectively also should decrease, cutting further into primary fences' profits, and, ultimately, reducing the overall rate of property theft. ${ }^{58}$ The deterrent effect on thieves resulting from the combined enforcement techniques, therefore, arises from direct risks of enforcement, indirect risks as a result of apprehension of the primary fence, and, possibly, decreased prices and lessened demand for stolen goods.

These anticipated effects have motivated enforcement against thieves

55. Research indicates that offenders engaged in crimes involving material gains are, as a group, profit maximizers. Ehrlich, The Deterrent Effect of Criminal Law Enforcement, 1 J. LEg. Srud. 259, 274-75 (1972) (offenders as a group respond to costs and gains in much the same way as those cngaged in legitimate activities); Ehrlich, supra note 54, at $111-12$ (same).

56. It should be noted that the effectiveness of enforcement as a threat or cost depends not only on the actual likelihood of arrest and conviction, but on the offender's perception of it. See F. Zimring \&. G. Hawkins, supra note 49, at 162.

57. See Taking the Offensive, supra note 18 , at 7 (arresting fence leaves thieves without outlet for stolen goods and without directions on what to steal).

58. If the price charged to customers increases, the profitability of buying stolen goods decreases so that at least knowing customers will buy less. See Roselius \& Benton, supra note 12, at 194 (as price increases, competitive position of legitimate dealers improves). Because both thieves and fences probably make many of the same marketing decisions that are made by legitimate businessmen, $i d$. at 204 , the anticipated marketing response to a decrease in secondary receivers' demand would be a decrease in the primary receiver's demand and, thus, in the supply of stolen goods, id. at 201 . If primary fences buy less from thieves, the theft rate should decline. Similarly, if decreased secondary demand prompts primary fences to lower their prices to purchasers, and thus also to lower prices paid to thieves for stolen goods, the incentive for theft, and so the incidence of theft, again should decline. See Ehrlich, supra note 55, at 274-75 (contending that offenders respond to costs and benefits). 
and primary fences. It has not been emphasized, however, that like effects may be achieved from enforcement against the aware customers of fences.

Enforcement against, and consequent deterrence of, such purchasers should further reduce the economic incentives to the other criminal participants in the redistribution channel and magnify the spiraling deterrent effect described above. If secondary market demand for stolen goods were reduced, the primary fence would be forced to compensate for that reduction, just as he must compensate for his own enforcement risks under current enforcement policy. ${ }^{50}$ Again, whether the primary fence were to increase prices charged or to decrease prices paid, he would reduce the incentive to secondary purchasers or thieves, respectively. Other alternative responses would have similar effects. If the fence were to attempt to mask the stolen goods before sale to make them appear legitimate, this would create an additional cost of doing business, for which the fence would similarly be forced to compensate, either through decreased prices paid or increased prices charged. ${ }^{\circ 0}$ If he were to restrict his sales to a few trusted customers, he still would face an additional risk of detection from their testimony, if they were to be apprehended as part of the new enforcement effort against secondary purchasers. Again the fence would be compelled to compensate for that increased risk. Moreover, in either case, the redistribution channel may be lengthened, ${ }^{61}$ further cutting into profits, elevating prices, and so decreasing demand. ${ }^{62}$

Thus, enforcement against criminal secondary purchasers could decrease the incidence of property theft by increasing the risks and costs of other criminal participants in the redistribution channel. These risks and costs serve as economic deterrents to the criminal conduct and add to the deterrent effect provided by the physical risks of apprehension and conviction. Thus shifting some enforcement resources

59. If there is a decrease in customer demand, a fence must change his marketing program, and these changes may also make him more vulnerable to enforcement efforts. Roselius \& Benton, supra note 12, at 201.

60. The process of disguising stolen goods is costly for several reasons, not the least of which is that the process usually requires one or more intermediaries who must be compensated for their labor. See id. at 192.

61. See id. (when stolen goods are disguised, redistribution channel may be Iengthened). If the primary fence limits sales to a few trusted customers without decreasing his supply, such customers are likely to be commercial receivers, because lay purchasers are only seeking articles to consume and, therefore, probably buy in smaller quantities. Thus, articles that might have been sold to lay purchasers would be sold instead to commercial purchasers, thereby lengthening the redistribution channel.

62. Id. at 201 (as channel lengthens, prices to secondary purchasers would increase and secondary demand and profitability for participants decrease). 
away from efforts at apprehension of thieves and primary fenceswhere the marginal returns are often small-to criminal secondary purchasers-thereby creating increased economic risks to all participants in the redistribution channel-can result in more effective enforcement.

\section{Enforcement Practices Against Criminal Secondary Purchasers of Stolen Goods}

Supplementing current property theft enforcement policy with a new focus requires an appropriate statutory framework and the design of practical enforcement tactics.

\section{Elements of the Substantive Criminal Law}

Several states have laws against criminal receipt of stolen goods that are inadequate to sustain effective enforcement strategies against those involved in the criminal redistribution network. Commentators previously have recognized these statutory inadequacies, ${ }^{63}$ but their discussions have emphasized the need to enhance the ability of the criminal justice system to reach primary fences. Nonetheless, these critiques point up deficiencies in many current statutes as applied to enforcement against criminal secondary purchasers of stolen goods as well.

Some of the criticisms have focused on the effect of certain provisions on investigative practices. For example, some statutes require that the purchased merchandise be "stolen" at the time of purchase. ${ }^{6 t}$ This requirement has been interpreted by some courts to include only those goods actually stolen and, as of the time of purchase, not recovered by enforcement authorities. ${ }^{65}$ That interpretation renders the common undercover "buy-sell" tactic impossible. Even if a thief were intercepted on his way to his fence, under this view the stolen articles would be considered recovered, and thus even the willing thief could not assist enforcement authorities by completing the sale.

Prosecutorial difficulties arising from various statutory requirements

63. See, e.g., J. Hall, supra note 5, at 173-232 (describing inadequacies in New York receiver statutes); Blakey \& Coldsmith, supra note 3 , at 1542-1611 (detailing statutory inadequacies and suggesting reforms).

64. See, e.g., Ill. AnN. Stat. ch. 38, § 16-1 (Smith-Hurd 1977); N.Y. Penal Law \$ 165.40 (McKinney 1975); Tex. Penal Code AnN. tit. 7, § 31.03(b) (Vernon Supp. 1980).

65. See, e.g., United States v. Monasterski, 567 F.2d 677 (6th Cir. 1977) (reversing conviction for knowing receipt of stolen property because goods lost their stolen character when recovered by security employees); People v. Jaffe, 185 N.Y. 497, 78 N.E. 169 (1906) (knowing receipt of stolen property impossible because goods recorered by owner no longer technically stolen).

In addition, this requirement has forced authorities to link a stolen object received by a fence with a particular theft in order to prove its origin. This is a major obstacle because marks of identification usually have been removed or altered by the time stolen goods pass through redistribution channels. Blakey \& Goldsmith, supra note 3, at 1551-58. 
also have been stressed. Among these difficulties is the requirement in some jurisdictions that the prosecution prove that the accused actually "received" rather than obtained control of or sold the goods. ${ }^{60}$ In addition, the prosecution may have difficulty obtaining appropriate sentences for convicted offenders in states where the offense is graded as either felony or misdemeanor according to the value of the merchandise purchased, rather than to the degree of the offender's criminal involvement. ${ }^{67}$

Statutory requirements such as these that hinder enforcement against primary fences would generate enforcement problems on the secondary level as well. Like the transaction between a thief and his fence, the crime committed by a secondary purchaser is "invisible": not only are sales generally accomplished in private, but even in those instances in which the goods are transferred openly, there is nothing inherently unlawful or suspicious about the merchandise. ${ }^{68}$ This suggests that secondary purchasers, 'like those on the primary level, can only be detected through undercover enforcement strategies.

Such strategies work best when at least three statutory conditions are satisfied. First, the receiver statute, either alone or in combination with a general attempt provision, should impose sanctions against the willing purchaser of goods believed to be stolen, ${ }^{69}$ whether they actually are stolen or not. This facilitates the use of "bait" property to make arrests. Second, the statutes should proscribe the sale of stolen property

66. See, e.g., N.C. GEN. STAT. \$ $14-71$ (Supp. 1979); R.I. GeN. Liws $\$ 11-41-2$ (1970). When receipt must be proved, the purchaser may counter successful prosecution by avoiding physical contact with the stolen goods. Blakey \& Goldsmith, supra note 3, at 1545.46 \& n.195. Statutory provisions proscribing the disposal of stolen goods as well as their receipt would make prosecution less problematic since police may only have esidence of a knowledgeable sale. See id. at 1546 (term "disposal" or "sale" could facilitate prosecution of modern receivers).

67. Criminal statutes that grade receiver offenses according to the value of the propexty received are still common. See The National Association of AtTorneys General, Legislative Responses to Dealing in Stolen Goods 15 (1975). This type of grading structure for criminal receipt of stolen goods is considered inadequate primarily because judicial leniency may be required even when the receiver is clearly a notorious offender. See J. Hald, supra note 5 , at 219 (person who deals regularly in stolen goods inflicts "graver harm" on society, and legislation that imposes uniform sanctions for all receivers is unjust); Blakey \& Goldsmith, supra note 3, at 1599 (reasons for inadequacy include difficulty in determining value, lack of accuracy, and obscuring of blameworthiness distinctions). To ensure that persistent felons receive heavier sentences, sereral states have passed habitual criminal statutes. See, e.g., Colo. REv. ST.1T. ANv. \$ 16-13-101 (1978); N.Y. Penal Law $\$ 70.10$ (McKinney Supp. 1979).

68. Blakey \& Goldsmith, supra note 3, at 1516. This serves to distinguish the sale of stolen property from the sale of narcotics, where the merchandise quickly can be confirmed as illegal.

69. Id. at 1552.55; see, e.g., People v. Rojas, 55 Cal. 2d 252, 257-58, 358 P.2d 921, 923.24, 10 Cal. Rptr. 465, 467-68 (1961); Ohio Rev. Code ANv. $\$ 2913.51$ (A) (Page 1975); cf. Modil. Penal Code $\$ 223.6$ (P.O.D. 1962) (concluding that belief merchandise probably was stolen is sufficient for conviction of any purchaser). 
as well as the "receipt" of such property. ${ }^{70}$ This would permit authorities to prove offenses against primary purchasers through the testimony of customers about their suppliers. ${ }^{71}$ Finally, the punishment for a single unlawful purchase should not be needlessly harsh, because extreme penalties may result in nonenforcement and much of the deterrent effect stems from the social stigma of involvement with criminal activity rather than from the threat of incarceration. ${ }^{72}$ Although these conditions are satisfied by the statutes of many jurisdictions, where the problems still exist such obstacles to effective enforcement should be removed.

\section{Possible Enforcement Strategies}

Effective enforcement efforts often require deception, especially in crimes without complainants, ${ }^{73}$ because such crimes might otherwise be impossible to detect. Receipt of stolen goods is such a crime, and undercover strategies are necessary to identify and apprehend criminal secondary purchasers. ${ }^{74}$

70. See, e.g., Cal. Penal Code $\S$ 496(1) (West Supp. 1979); Ohio Rev. Code Ann. \$ 2913.51(A) (Page 1975).

71. The sentence of a criminal secondary purchaser, of course, may be negotiated. In many cases, an offer of immunity to assist in apprehending a primary fence may be justified. Indeed, this may reduce some of the social costs associated with enforcement against primary fences. Although current strategies utilize information from thieves to learn about specific primary fences, even if it means offering grants of immunity or other sacrifices in order to elicit cooperation, in some cases the same information may be obtained from criminal secondary purchasers who are less criminally active and, arguably, less dangerous sources.

72. The deterrent effect of enforcement is achieved through a combination of forcescommunity recognition of the harm, destruction of the self-image of legitimacy, the greater risk of apprehension and conviction, and the sentence exacted. See F. Zimaing \& G. HAwrins, supra note 49, at 81-83. Of these, the possibility of incarceration may be the least significant deterrent. See J. Conklin, The Impact of Crime 131 (1975) (formal criminal sanctions are probably less important in controlling behavior than informal sanctions such as group censure and bystander intervention).

73. See 1 Working PAPERs, supra note 48, at 308.

74. Tactical designs must be bounded by the doctrine of entrapment. See, e.g., N.Y. Penal Law $\$ 40.05$ (McKinney 1975) (affirmative defense satisfied if public official actively induces or encourages another person to engage in offense and creates substantial risk that person was not otherwise disposed to commit offense). An enforcement ploy must not lure an otherwise innocent person into a criminal act or "implant in [his] mind ... the disposition to commit the alleged offense and induce its commission." Sorrells v. United States, 287 U.S. 435, 442 (1932). The artifice is acceptable, however, if agents "merely afford opportunities or facilities for the commission of the offense." Id. at 441 . The majority view espoused in United States v. Russell, 411 U.S. 423, 436 (1973) and Hampton v. United States, 425 U.S. 484, $489-90$ (1976) focuses on the "origin of intent" test, whereby the accused's predisposition to engage in the crime is examined. The minority view, or the "police conduct" test, focuses on whether the police conduct was a proper use of government power. P. Lewis \& $\mathrm{K}$. Peoples, The Supreme Court ANd the Criminal. Process 484 (1978).

Issues similar to those that would be raised by undercover enforcement ploys directed at criminal secondary purchasers have been raised by enforcement campaigns against 
Currently, undercover property theft enforcement strategies fall into two modes. In the first, the target is the unknown offender. For example, officers may pose as fences at the primary level to apprehend thieves and, occasionally, competing primary fences. ${ }^{75}$ This method does not actively search for offenders, but rather attracts them, ${ }^{76}$ and has been praised for obtaining large numbers of arrests and convictions at relatively low overall cost. ${ }^{77}$

In the second mode, the target of the undercover strategy is a specific offender. Thus, for example, after a primary fence has been identified by several thieves, undercover officers may pose as thieves or customers in order to investigate and make an arrest. ${ }^{78}$ Such procedures are the only feasible methods for apprehending most primary-level fences who maintain regular establishments where other criminals come to engage in transactions. In order to employ the first strategic mode against primary fences, undercover officers would have to pose as thieves or customers and actively search for offenders on a "hit-or-miss" basis; such a search could be construed as harassment by legitimate members of the community.

Both modes of undercover enforcement are workable against criminal secondary purchasers. When the first mode is employed, such tactics may be ancillary to any others already in effect. The role played by the officer will be the same role now played to apprehend thieves in "sting"-type operations-that of the primary fence. If an undercover operation were to foster a reputation for willingly selling certain types of stolen goods in addition to buying them, secondary purchasers might contact these enterprises. Officers could engineer a sale that could be preserved on videotape, just as purchases from thieves are at present; arrests of buyers as well as sellers could be made at the end of the

patrons of prostitutes. See N.Y. Times, Nov. 16, 1977, at 17, col. 5 (initial drive against patrons of prostitutes discontinued in part because of protests of entrapment). $A$ current operation against prostitutes' patrons is considered free of entrapment problems because the undercover policewomen dress sedately and do not approach or initiate conversations with men. See N.Y. Times, July 4, 1978, at 8 , col. 1. The analogy to secondary receivers suggests that undercover agents must represent the merchandise as stolen and should refrain from active solicitation. Moreover, the price should be the same as or higher than the going rate in the stolen goods market. Cf. Warner, The Troubling Ethics of Abscam, TIME, Feb. 18, 1980, at 21 (suggesting there may be entrapment problems in recent FBI "sting" because of hard-sell tactics by over-anxious contacts).

75. See p. 1230 supra.

76. This method recently was employed by FBI undercover agents against members of the United States Congress to enforce federal antibribery statutes. The probe and premature disclosure generated widespread controversy. See, e.g., Wash. Post, Feb. 3, 1980, at Al, col. 1.

77. See Taking the Offensive, supra note 18 , at 16-19.

78. For a full discussion of buy-sell undercover specialized antifencing strategies that are used to deal with local fencing problems, see Strategles, supra note 8 , at 76.82. 
project, and the videotape evidence would aid in the conviction of both. Obviously, tactical strategies within this first mode will vary in different communities depending on the local practices. ${ }^{79}$ Where most secondary criminal purchases are made from "neighborhood" fences ${ }^{\mathbf{8 0}}$ selling illicit merchandise in apartments and taverns, undercover officers may be placed in those parts of town in which these enterprises flourish, attempting to establish themselves as local connections for stolen goods. If successful, such ploys eventually should result in the attraction and apprehension of both thieves and secondary purchasers.

The second mode of enforcement may be appropriate when a specific segment of the community or a specific individual is suspected of regular secondary criminal purchases. In such cases, officers posing as fences may peddle stolen articles to suspects. This tactic was successfully employed against certain business people in Portland, Oregon. ${ }^{81}$ There, a policewoman posing as a fence claimed that her boyfriend, a drug addict, had stolen the television sets she was selling. Of approximately twenty people solicited, there was only one refusal. After agreeing to buy, the offenders were arrested and prosecuted.82

\section{Conclusion}

The criminal secondary purchaser of stolen goods contributes significantly to profit-motivated property theft. Rather than neglect him because he engages in less criminal activity, criminal justice should shift a portion of current property theft enforcement resources from the primary fence and thief to this offender. With an appropriate statutory framework and workable enforcement strategies, such a program should reduce crimes against property by reducing the economic benefits derived from them.

79. Id.

80. See Blakey \& Goldsmith, supra note 3, at 1529-31; Hearings, supra note 8, at 44 (statement of Franklyn H. Snitow, Assistant District Attorney, New York County, N.Y.) (neighborhood fence found in every neighborhood deals directly with thief and openly sells to buyers).

81. Boggs Interview, supra note 17.

82. The experiment was conducted by the antifencing detail, headed by Sergeant Harry Boggs, in Portland, Oregon. Some of the various retailers solicited bought for personal consumption and some for resale. Chasan, supra note 16, at 17. To one commentator, the experiment implied that "big-time fences are wasting a lot of time and money trying to look legitimate, because the public just doesn't care." Id.

Because the goods were not actually stolen, the offenders were charged with attempted receipt of stolen property. Those convicted received light sentences-small fines and public service work. An unexpected benefit from the program was a positive response to this enforcement campaign from the underprivileged portion of the community who blamed the willing buyers of stolen goods for repeated burglary victimizations. Boggs Interview, supra note 17. 